Review

\title{
Fused in Sarcoma (FUS) in DNA Repair: Tango with Poly(ADP-ribose) Polymerase 1 and Compartmentalisation of Damaged DNA
}

\author{
Maria V. Sukhanova ${ }^{1, *}$, Anastasia S. Singatulina ${ }^{1}$, David Pastré ${ }^{2}$ and Olga I. Lavrik ${ }^{1}$ (i) \\ 1 Institute of Chemical Biology and Fundamental Medicine, SB RAS, 630090 Novosibirsk, Russia; \\ lasty@ngs.ru (A.S.S.); lavrik@niboch.nsc.ru (O.I.L.) \\ 2 Laboratoire Structure-Activité des Biomolécules Normales et Pathologiques, INSERM U1204, \\ Université Paris-Saclay, 91025 Evry, France; david.pastre@univ-evry.fr \\ * Correspondence: mary@niboch.nsc.ru; Tel.: +7-383-363-5196
}

Received: 12 August 2020; Accepted: 21 September 2020; Published: 24 September 2020

\begin{abstract}
The fused in sarcoma (FUS) protein combines prion-like properties with a multifunctional DNA/RNA-binding domain and has functions spanning the regulation of RNA metabolism, including transcription, pre-mRNA splicing, mRNA transport and translation. In addition to its roles in RNA metabolism, FUS is implicated in the maintenance of DNA integrity. In this review, we examine the participation of FUS in major DNA repair pathways, focusing on DNA repair associated with poly(ADP-ribosyl)ation events and on how the interaction of FUS with poly(ADP-ribose) may orchestrate transient compartmentalisation of DNA strand breaks. Unravelling how prion-like RNA-binding proteins control DNA repair pathways will deepen our understanding of the pathogenesis of some neurological diseases and cancer as well as provide the basis for the development of relevant innovative therapeutic technologies. This knowledge may also extend the range of applications of poly(ADP-ribose) polymerase inhibitors to the treatment of neurodegenerative diseases related to RNA-binding proteins in the cell, e.g., amyotrophic lateral sclerosis and frontotemporal lobar degeneration.
\end{abstract}

Keywords: fused in sarcoma; DNA repair; poly(ADP-ribose) polymerase; poly(ADP-ribose); protein phase separation

\section{Introduction}

Throughout their lifespan organisms are constantly exposed to genotoxic agents, both exogenous and endogenous. A rough assessment has revealed that up to 70,000 DNA damage events occur per human cell per day [1]. Under these conditions, preserving cell genome integrity is one of the most important challenges faced by multicellular organisms. Notably, unrepaired DNA damage contributes to the appearance of a pathological mutation [2-4]. The maintenance of genome stability is achieved by the machineries associated with the DNA damage response (DDR) and the cell death pathways that carry out detection of DNA damage or a signal of its presence to orchestrate DNA repair and induce cell death upon massive DNA damage, respectively [5,6]. For a long time, it has been believed that RNA-binding proteins (RBPs) interfere indirectly with the DDR through post-transcriptional regulation of gene expression [7-10]. Nonetheless, more and more studies are revealing the direct functions of many RBPs in the presence of DNA damage, e.g., sensing, signalling, and repair [11-13]. In this regard, poly(ADP-ribose) polymerases (PARPs), which are DNA damage sensors, may provide the basis for the control of RBPs over DNA repair and accordingly aroused special interest recently [14-19]. Indeed, DNA damage followed by PARPs' activation is accompanied with protein poly(ADP-ribosyl)ation (PARylation) through covalent attachment of ADP-ribose moieties and 
the formation of an ADP-ribose chain: poly(ADP-ribose) (PAR) [20-22]. PAR is a polymeric molecule that shares several features with RNA, including a high negative charge and structural diversity (size, chain length, and branching complexity) [23-25]. A large body of evidence suggests that many RBPs interact with PAR and/or undergo post-translational modification through PARylation during genotoxic stress [26,27]. Moreover, RBPs contain low-complexity regions with self-adhesive properties abundantly as compared to other proteins. Low-complexity domains (LCDs), also called intrinsically disordered regions, are considered key components of membrane-less assemblies such as DNA damage foci, P-bodies or stress granules formed under stressful conditions in the cell [28-31]. PAR, in turn, may serve as a scaffolding factor for these RBP-containing assemblies [16]. Just as many RBPs, fused in sarcoma (FUS) combines self-adhesive LCDs with multifunctional DNA/RNA-binding domains. FUS is involved in the regulation of RNA metabolism, including transcription, pre-mRNA splicing, mRNA transport and translation [32]. In addition to its role in RNA metabolism, FUS was recently implicated in the maintenance of DNA integrity in response to DNA damage [33,34]. In particular, FUS is mainly a nuclear protein [35] that interacts with DNA repair factors and is associated with DNA damage-induced formation of nuclear foci [17,36-40]. Nonetheless, the exact functions of FUS in DNA repair remain unclear. In this review, we highlight the role of FUS in the maintenance of genome integrity, focusing on PARylation events and on how the FUS-PAR interaction may be connected with DNA repair.

\section{Intrinsically Disordered Regions and Prion-Like Properties of FUS}

The protein called fused in sarcoma (FUS; also known as translocated in liposarcoma; TLS) was first identified in human myxoid liposarcomas $\sim 30$ years ago, suggesting that this protein plays a critical part in cancers [41,42]. In liposarcoma, a chromosomal translocation leads to the fusion of two genes, FUS and UPR-regulated CCAAT/enhancer-binding protein homologous protein, resulting in the synthesis of a chimeric protein that acts as a transcription factor enhancing cell proliferation and promoting tumour progression [41]. FUS, along with Ewing's sarcoma (EWS) and TATA-binding protein-associated factor 15 (TAF15), belongs to the FET family of RBPs that are highly conserved and perform functions primarily related to RNA metabolism [43,44]. FUS is a 526-amino-acid-long protein that possesses a serine/tyrosine/glycine/glutamine (SYGQ)-rich $\mathrm{N}$ terminus of low complexity, three arginine/glycine/glycine (RGG)-rich regions (named RGG1-3), a conserved RNA recognition motif, a zinc finger motif and a proline-tyrosine nuclear localisation signal at the C-terminus $[45,46]$ (Figure 1 ). The C-terminal domains of FUS comprising the RNA recognition motif, RGG and zinc finger motifs mainly participate in the binding of FUS to RNA, DNA and PAR [47-51]. On the other hand, FUS's unstructured N-terminal domain of low complexity is mainly associated with FUS self-interactions caused by homotypic multivalent interactions $[52,53]$. 
Exon structure of FUS gene

\begin{tabular}{|c|c|c|c|c|c|c|c|c|c|c|}
\hline $1|2| 3$ & 4 & 5 & 6 & $|7| 8 \mid$ & 9 & 10 & 11 & 12 & 13 & 14 \\
\hline
\end{tabular}

FUS protein domains

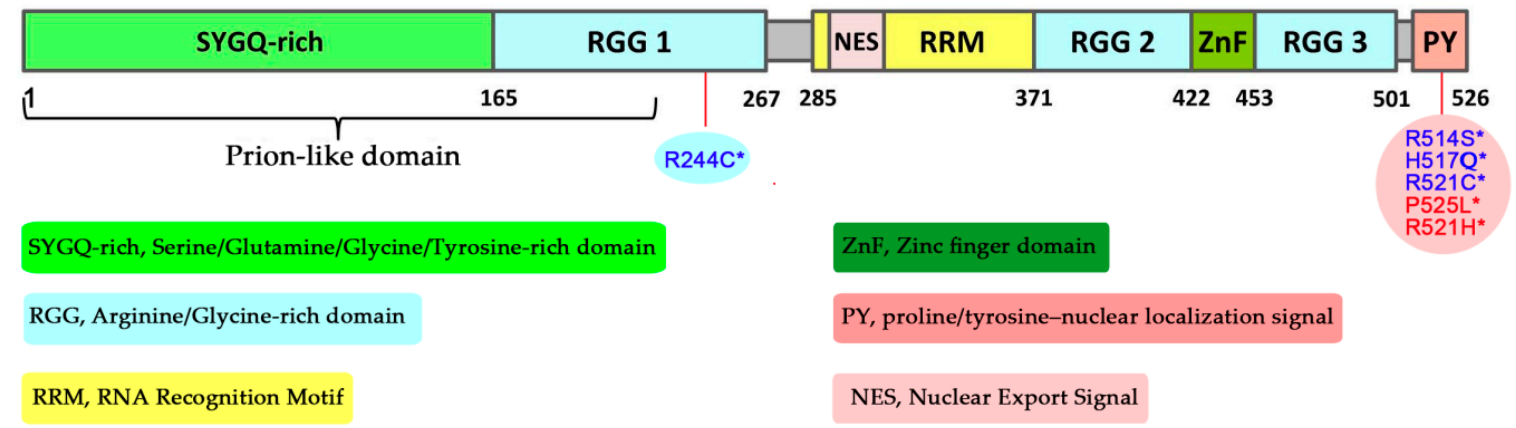

Figure 1. A schematic diagram of exon structure of the FUS gene and domain structure of the FUS protein [54]. * Mutations identified in patients with familial amyotrophic lateral sclerosis (fALS) and implicated in DNA repair and DDR $[37,40]$.

\section{Higher-Order Assembly and Phase Separation of the FUS Protein for the Formation of Membrane-Less Assemblies in the Cell}

Notably, through its long N-terminal LCD with prion-like properties, higher-order multimolecular assembly of FUS either alone or in the presence of RNA gives rise to diverse structures including aggregates, hydrogels, amyloid fibrils and liquid droplets in vivo that have been the subject of intense research since pathological mutations in FUS were directly associated with two major neurodegenerative diseases, amyotrophic lateral sclerosis (ALS) and frontotemporal lobar degeneration (FTLD), and the identification of cytoplasmic inclusions of FUS in neurons of the affected patients $[41,52,53,55-57]$. In agreement with its ability to aggregate, among more than 200 yeast-prion-like proteins that have been identified in the human proteome [58], FUS has been ranked $15^{\text {th }}$ for its prion-like properties and 1st among RBPs [59]. In particular, it has been shown that SYGQ- and glycine-rich regions at the $\mathrm{N}$ terminus of FUS have prion-like properties and accordingly play an important role in FUS aggregation. In line with this notion, a truncated FUS protein lacking the $\mathrm{N}$ terminus is not able to form droplets or aggregates both in vitro and in vivo [17,56,60-64]. Weak homotypic multivalent intermolecular interactions occur between N-terminal LCDs thereby resulting in FUS self-assembly into liquid-like dynamical compartments as a single component. Heterotypic interaction with other proteins and/or nucleic acids can lead to heterogeneous higher-order structures giving rise to higher complexity in terms of composition, shape and dynamics and most probably biological functions $[52,55,64,65]$. In this way, it has been suggested that phase transition, in particular liquid-liquid phase separation (LLPS) of protein or protein-nucleic acid mixtures underlies the emergence of membrane-less compartments such as nucleoli, Cajal bodies, gemini of Cajal bodies, Nuage bodies, speckles, paraspeckles, DNA damage foci, stress granules and P-bodies in the cell $[28-30,66]$. In the emerging field of phase separation biology, FUS has received even more attention since pathological mutations in the LCD that impair FUS were shown to trigger a phase transition from a reversible liquid-like droplet or gel-like state to irreversible solid-like states possibly promoting the formation of cytoplasmic inclusions of FUS found in ALS and FTLD [66]. Taking into account that FUS undergoes phase separation and interacts with other macromolecules such as RNA, DNA or PAR, FUS is regarded as an important player in the creation of membrane-less compartments in vivo under physiological and stressful conditions [67,68]. Indeed, nuclear FUS has been detected in association with DNA damage foci [17,37], paraspeckles [69] and SMN1 bodies (Gems) [70], whereas cytoplasmic FUS is recruited into stress granules or P-bodies [71-80] and neuronal RNA granules [81,82] (Figure 2). 


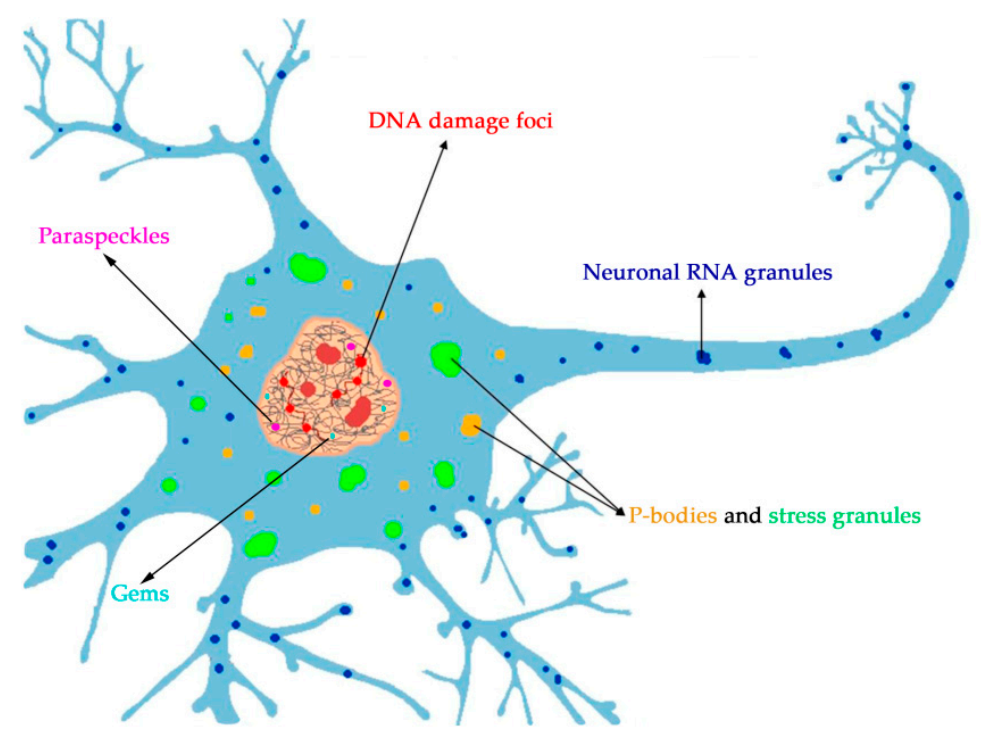

Figure 2. Schematic illustration of a neuronal cell and membrane-less compartments generated with the participation of FUS in the nucleus and cytoplasm. We corrected the Figure 2 (Please, see the attached file).

Accordingly, the functions of FUS in DNA repair may be related to its capacity to induce the formation of dynamic compartments that regulate DNA repair through protein phase separation. Although numerous studies have shown that FUS can be recruited to a region containing DNA damage in the nucleus, whether FUS directly affects the efficiency of DNA repair, by promoting the emergence of DNA repair foci, is still an open question.

\section{Direct Functions of FUS in DNA Repair}

As mentioned above, FUS mainly features a nuclear localisation [83], while a smaller proportion of FUS is found in the cytoplasm under physiological conditions [48,82]. For a long time, FUS has been known to be involved in the regulation of RNA metabolism [43,84]. FUS binds preferentially to a nascent GU-rich mRNA transcript and has been identified as a component of membrane-less organelles associated with RNA processing such as SMN1 bodies (Gems) in the nucleus and RNA granules or stress granules in the cytoplasm [70].

More recently, the recruitment of FUS to DNA damage-induced foci in the nucleus has drawn attention to its involvement in DNA repair processes [17,38,40,51]. DNA damage repair proceeds through one of five major pathways: direct repair of certain types of UV light-induced photo-lesions or methylated bases; homologous recombination (HR) or nonhomologous end-joining (NHEJ) to repair double-strand breaks (DSBs); nucleotide excision repair of bulky lesions; base excision repair (BER) of damaged bases, apurinic/apyrimidinic sites and single-strand breaks (SSBs); and mismatch repair of unpaired bases [85]. Numerous studies indicate that FUS's functions in the DDR are associated with DNA strand break signalling and the repair of oxidative DNA damage types such as oxidised DNA bases and DNA SSBs and DSBs [33,34]; therefore, here we focus on the possible participation of FUS in HR, NHEJ or BER pathways (Figures 3 and 4). 
(a) Homologous recombination

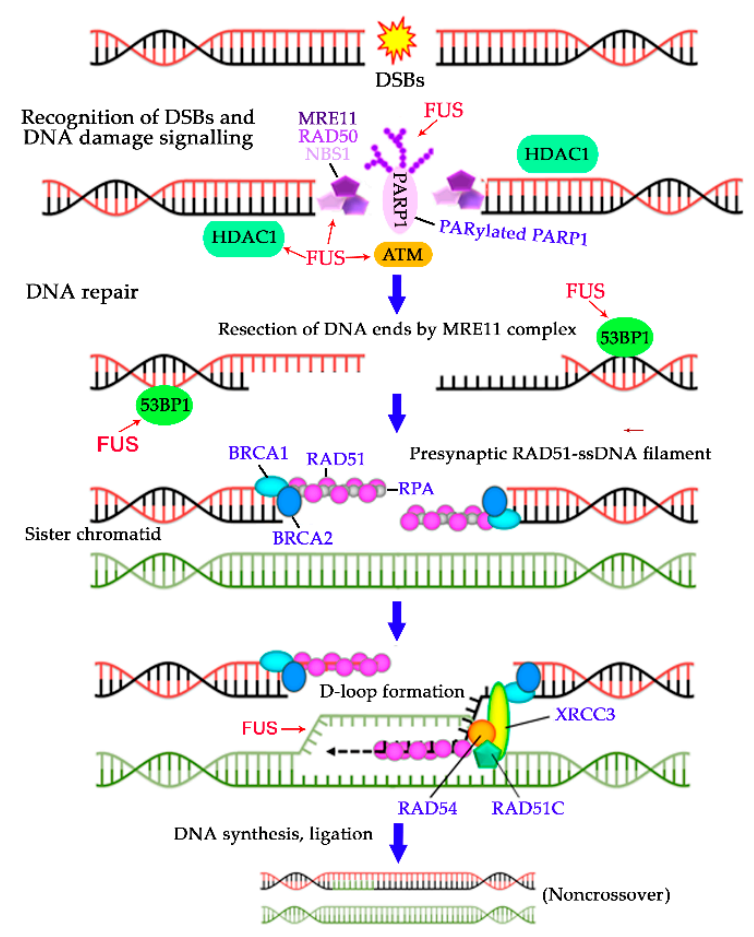

(b) Nonhomologous end joining

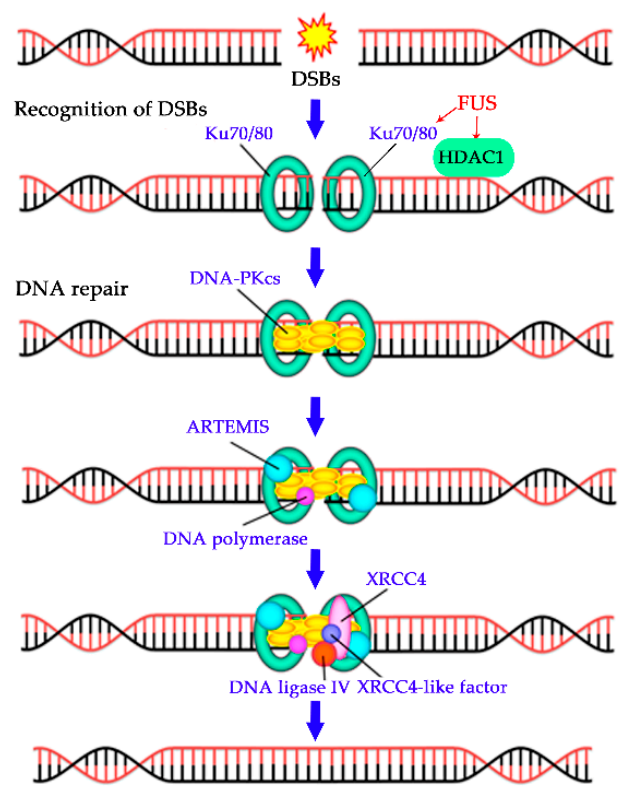

Figure 3. The involvement of FUS in double-strand DNA break (DSB) repair pathways. Schematic overview of HR, NHEJ illustrating basic steps of these pathways along with the proteins implicated in each step [86]. (a) The influence of FUS on HR. Simplified scheme for HR. The Mre11/Rad50/NBS1 complex starts resection on the DSBs to generate single stranded DNA. The ssDNA is first coated by Replication protein A (RPA), which is subsequently replaced by Rad51 with the help of BRCA1 and BRCA2. These Rad51 nucleoprotein filaments mediate strand invasion on the homologous template. The invading $3^{\prime}$-end of ssDNA serves as a primer for DNA synthesis. D-loop strands extended by DNA repair synthesis dissociate from their sister chromatid complements and reanneal with their original complementary strands. Additional DNA synthesis in the reannealed DNA duplex and ligation of the remaining single strand nicks complete the repair in the case of synthesis-dependent strand-annealing model of D-loop resolution, forming non-crossover products. FUS interacts with histone deacetylase 1 (HDAC1) and PARylated PARP1, binds to a D-loop intermediate and affects DSB-dependent accumulation of ATM (Ataxia-telangiectasia mutated serine-proteins kinase), NBS1 (Nijmegen breakage syndrome 1) and 53BP1 (p53-binding protein 1) [37,49]. (b) The effect of FUS on NHEJ. Simplified scheme for NHEJ. The two broken DNA ends are processed by the action of the end-binding Ku70/80 heterodimer complex, DNA-dependent protein kinase, catalytic subunits, (DNA-PKcs), artemis, DNA polymerase and ligated by DNA Ligase IV-XRCC4 complex. FUS interacts with HDAC1 and affects accumulation of Ku70/80 at DSBs [37]. 


\section{Base excision repair or single-strand break repair} (short-patch pathway)

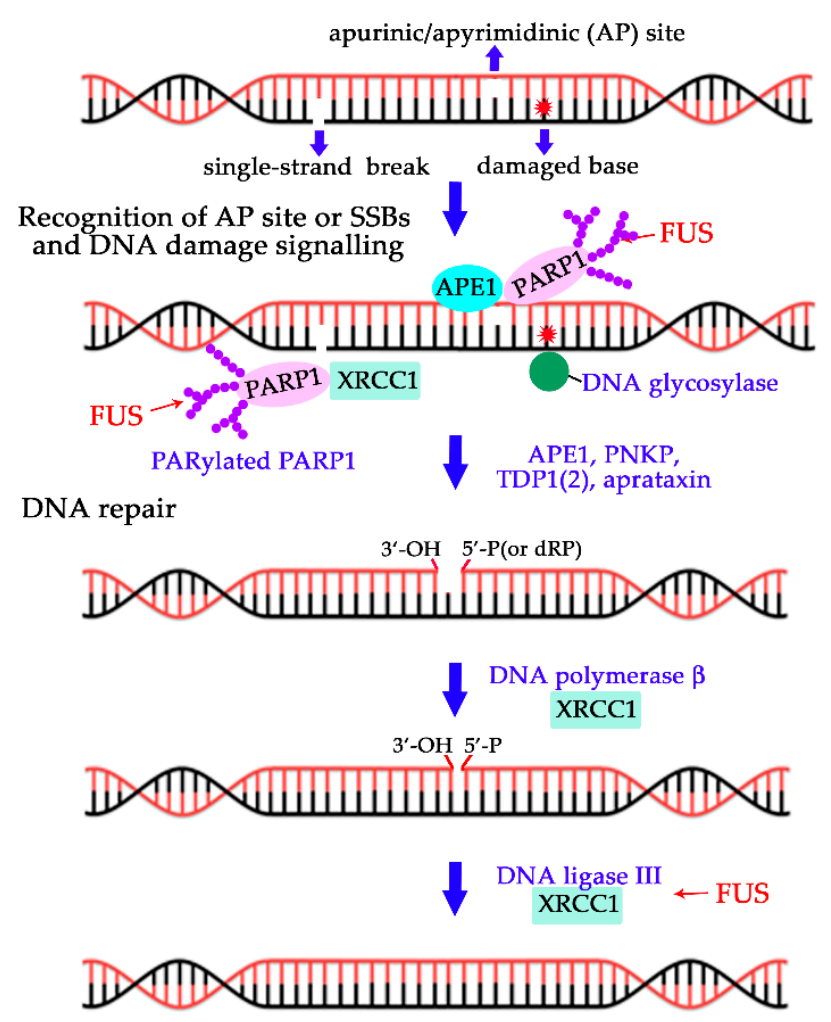

Figure 4. The involvement of FUS in base excision repair (BER) or single-strand break (SSB) repair pathways. Simplified scheme for BER/SSBR short-patch pathway [87]. Monofunctional DNA glycosylases catalyse the removal of the damaged base through cleavage of the $C 1^{\prime}-N$-glycosylic bond, leaving an AP site. AP endonuclease1 (APE1) cleaves AP site, DNA polymerase $\beta$ inserts a single nucleotide and removes the $5^{\prime}$-deoxyribose phosphate $(\mathrm{dRP})$, and the resulting nick is sealed by DNA ligase III-XRCC1 complex. In the case of SSB, the $5^{\prime}$-and $3^{\prime}$-termini containing blocking modifications can be converted to $5^{\prime}$-phosphate $(\mathrm{P})$ and $3^{\prime}$-hydroxyl $(\mathrm{OH})$ moieties by APE1, polynucleotide kinase 3'-phosphatase (PNKP), tyrosyl-DNA phosphodiesterase 1/2 (TDP1, TDP2) and/or aprataxin. AP sites, SSBs, arising endogenously or exogenously are bound by PARP1, which is then activated and autoPARylated. AutoPARylated PARP1 recruits repair proteins, in particular XRCC1 to the SSB [87]. The impact of FUS on BER is as follows: FUS interacts with PARylated PARP1 and the DNA ligase III-XRCC1 complex, thereby stimulating the ligation of DNA ends [40].

\subsection{A FUS Gene Knockdown in Mice and Cells Impairs HR}

One of the first pieces of evidence that FUS may play an important part in the maintenance of genome stability has been provided by experiments with FUS-deficient mice and cells originating from the knockout animals. The first FUS knockout mice were generated by disruption of a region (homologous to the 12th exon of the human gene) encoding a domain including the zinc finger motif (Figure 1), resulting in a lack of normal transcripts or protein expression in mice [88]. The homozygous mouse pups fail to suckle, and most of them die shortly, within $16 \mathrm{~h}$, after birth. $\mathrm{FUS}^{-/}$primary fibroblasts or B lymphocytes derived from the knockout mice are characterised by genomic instability, and the lymphocyte proliferative response to mitogens is significantly affected. Those authors have suggested that FUS acts as a modulator or effector of gene expression by binding to RNA and thereby participates indirectly in the cellular response to DNA damage or mitogenic stimuli [88]. Another strain of FUS-deficient mice has been created via disruption of a region homologous to the $8^{\text {th }}$ exon of the human gene [89] (Figure 1). These $\mathrm{FUS}^{-{ }^{-}}$ animals manifest complete male sterility and reduced fertility of females; moreover, these mice and 
their fibroblasts (FUS ${ }^{-1-}$ )are sensitive to ionising radiation. Detailed analyses have revealed that the FUS deficiency causes a defect in homologous pairing and synapsis during HR, thus leading to degeneration of spermatocytes (Figure 3a). According to measurements of homologous DNA-pairing activities in cell extracts, the contribution of FUS to ATP-independent annealing of complementary single-stranded DNAs and D-loop formation in superhelical double-stranded DNA has uncovered its role in homologous pairing [49]. Therefore, FUS may contribute to meiotic HR through interaction with a D-loop intermediate (Figure 3a). Meiotic HR is a programmed event, but HR is also one of two major DSB repair pathways, and homologous DNA pairing is an essential step in the repair pathway [90]. Consequently, defects in the repair of DNA damage produced by ionising radiation in FUS knockout animals and cells may be explained by impaired DSB repair via HR.

\subsection{Deficiency of FUS or Mutations of FUS Affect the Repair of DNA Strand Breaks}

Because FUS deficiency increases genome instability in animal and cell models, FUS has been the subject of further research on its role in the repair processes. As mentioned above, eukaryotic cells have evolved two pathways to repair DSBs, namely, HR and NHEJ (Figure 3a,b) [86,90]. Other experimental pieces of direct evidence for the participation of FUS in DSB repair come from examination of the effects of a knockdown of FUS by a small interfering RNA or expression of fALS-associated mutant FUS versions (R244C, R514S, H517Q or R521C) in murine primary neuronal culture and/or human osteosarcoma U2OS cells [37]. Upon DNA damage, FUS depletion leads to a decrease in the level of $\mathrm{H} 2 \mathrm{AX}$ phosphorylation, an impairment of DSB repair foci creation and deficient accumulation of DDR proteins such as p53-binding protein 1 (53BP1), Nijmegen breakage syndrome 1 (NBS1), phospho-ATM (ataxia telangiectasia mutated) and Ku70 (Figure 3a,b). The role of FUS in DSB repair is further underscored by results of FUS depletion: decreased HR and NHEJ efficiency and elevating the number of DNA damages in primary neuronal culture [37]. Besides, FUS directly associates with chromatin [91] and with a remodelling factor such as histone deacetylase 1 (HDAC1) [37]. HDAC1 plays an important part in the promotion of DNA DSB repair in post-mitotic neurons [92]. Furthermore, the expression of FUS mutants defective in their interaction with HDAC1 impairs both NHEJ and HR pathways in the U2OS-GFP cell line [37]. These observations indicate an impaired capacity to repair a DNA DSB when expression levels of FUS are low or FUS is mutated in the cell. The functions of FUS in NHEJ and HR repair pathways are therefore clearly non-transcriptional.

In addition to its functions in DSB repair, FUS is involved in DNA SSB repair in HEK293 cells [40]. FUS co-immunoprecipitates with BER players such as XRCC1 and DNA ligase III (Lig III) and stimulates Lig III activity via direct interaction. Moreover, a CRISPR/Cas9-mediated knockout of FUS in HEK293 cells reduces the efficiency of SSB repair [40]. Defective DNA repair of oxidative DNA damage is observed in induced pluripotent stem cell lines derived from ALS patients carrying either the R521H or P525L mutation of FUS (Figure 1), which promotes the formation of cytosolic FUS aggregates at the expense of the pool of nuclear FUS [66,93].

These findings therefore define FUS as a novel participant of DNA break repair processes that plays an upstream role in DSB signalling; these data also point to a functional link to HR, NHEJ and BER/SSB repair via interaction with DNA intermediates and/or repair factors. In the case of DSB repair (Figure 3a,b), FUS facilitates the initial recruitment of DNA damage signalling proteins to DNA lesions and regulates HDAC's chromatin-remodelling activity [37]. In the case of SSB repair (Figure 4), FUS interacts with the XRCC1-DNA ligase III complex and stimulates the SSB ligation step [40]. On the other hand, we cannot rule out the possibility that FUS has functions downstream of ATM or DNA-PK in response to DNA breaks. This is because FUS phosphorylation drives its translocation to the cytoplasm under genotoxic stress thereby possibly affecting FUS functions in RNA metabolism [36,39].

\subsection{FUS Is Connected to DNA Strand Breaks by PARPs' Signalling Activities}

Although in vitro studies indicate that FUS directly binds to single- or double-stranded DNA or G-quadruplexes in telomeres [49,94], how FUS is recruited to the sites of DNA damage in the cell has been 
an open question. FUS recruitment to DNA repair sites has been analysed owing to the development of the laser micro-irradiation technique able to generate a spatially controlled DNA damage region in the cell nucleus $[37,38,40]$. The first evidence that FUS can be translocated directly to DNA damage foci was obtained in cells subjected to $405 \mathrm{~nm}$ laser micro-irradiation. Moreover, FUS recruitment to DSBs is specifically dependent on the activity of PARP1, thus pointing to an interaction between FUS and the PAR produced by PARP1 at DNA damage sites [51]. Later, PAR-dependent FUS accumulation at damaged-DNA sites has been detected in response to oxidative DNA damage induced by a UVA (320-400 nm) laser, suggesting the recruitment of FUS not only to DSBs but also to SSBs generated directly or indirectly during the repair of oxidised bases in DNA [38]. Therefore, DNA damage-dependent activation of PARPs and the synthesis of PAR are some of the ways in which FUS can be recruited to sites of DNA damage $[37,38,40]$. PARPs, primarily PARP1 and PARP2, can directly recognise damaged DNA, and their binding to it results in PARP activation $[95,96]$. PARP enzymes use $\mathrm{NAD}^{+}$as a substrate and catalyse the transfer of an ADP-ribose residue from $\mathrm{NAD}^{+}$to target protein-acceptors, leading finally to the synthesis of ADP-ribose chains (PAR) attached to proteins, mainly PARPs themselves [21] (Figure 5).

PAR chains is commonly linked to Lys/Arg or Glu/Asp residues attached to the C1" or C1",C2", C3" atoms of ADP-ribose with the formation of ketoamine and carboxyl ester, respectively (Figure 5). Moreover, amino acid specificity of PARP1 (PARP2) from Glu/Asp to Ser residue can be changed under influence of other protein factors such as histone PARylation factor $1[95,97]$.

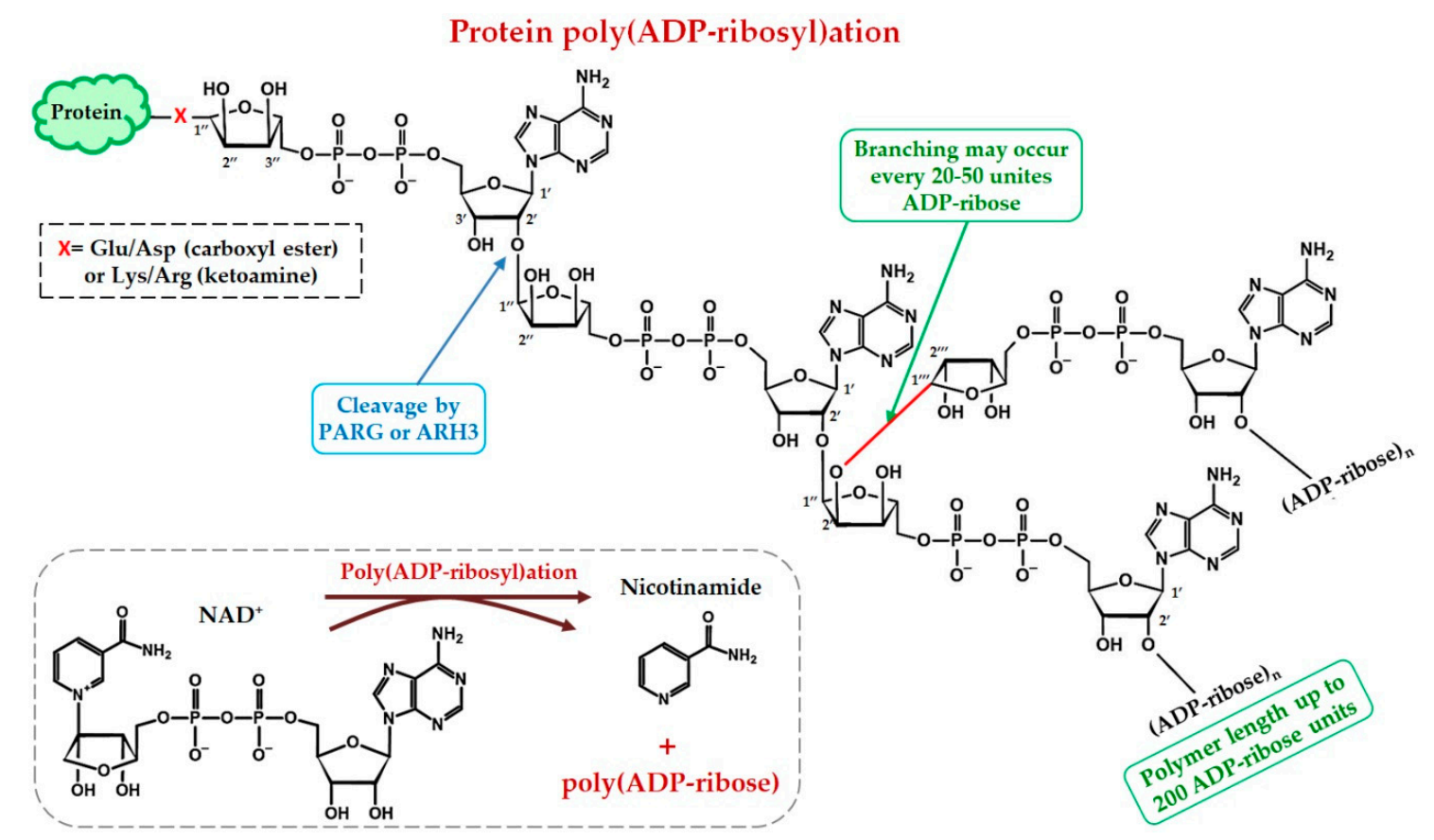

Figure 5. A diagram of the structure of PAR and protein PARylation. The scheme illustrates chemical structure of $\mathrm{NAD}^{+}$and a chain of ADP-ribose units linked by the $\alpha\left(2^{\prime}-1^{\prime \prime}\right) O$-glycosidic bond between ribose residues (linear chain) and by the $\alpha\left(2^{\prime \prime}-1^{\prime \prime \prime}\right)$ glycosidic bond between two nicotinamide-proximal ribose residues (branching). PARG and ARH3 is the main enzymes that degrade PAR and possesses exoand endoglycosidase activities hydrolysing the glycosidic bonds between ribose units of PAR [98,99].

Protein PARylation is a reversible process mainly due to poly(ADP-ribose) glycohydrolase (PARG) activity and ADP-ribosyl-acceptor hydrolases 3 (ARH3), which catalyse the cleavage between ADP-ribose structural units at the terminal position and inside the polymer, thereby releasing ADP-ribose or oligo(ADP-ribose), respectively [98,99]. Thus, the action of PAR-degrading enzymes makes protein PARylation a dynamic and reversible post-translational modification and plays an important role in the regulation of DNA repair [98-100]. Protein PARylation, PAR length and formation 
of protein-free PAR molecules all contribute to the regulation of DNA repair, in particular, through the binding of proteins to PAR or their PARylation $[16,21,25,100]$. Therefore, PAR (either attached to proteins or free), because of its biochemical properties and tight regulation of its synthesis and degradation by PARP and PARG/ARH3 activities, is considered a critical factor that orchestrates reversible assembly of DNA repair compartments $[16,25,99,101]$. It is commonly accepted now that PARPs and PARylation regulate DSB and BER/SSB repair $[102,103]$. Recent research showed that FUS binds to PAR non-covalently and/or can be PARylated in vivo and in vitro $[17,26,27,40,101]$. Consistently with this notion, the FUS interaction with PAR after DNA damage constitutes the missing link between FUS and DNA repair events $[17,38,40,51,56,101]$. In line with this view, PAR synthesis at DNA damage sites induces the relocation of FUS to DNA damage foci $[17,38,40,51]$. Furthermore, inhibition of PARP activity impairs FUS accumulation at sites of laser-induced damage in the cell, and it is likely that the absence of PAR prevents FUS from being directed to DNA damage sites [17,38,51].

Consequently, FUS may take part in DNA strand break repair in a PAR-dependent manner, although little is known about the functional significance of FUS-PAR interactions in DNA repair $[40,104]$. One supposition is the unusual capacity of FUS to form a liquid-like compartment making it an ideal organiser of DNA repair compartments $[17,101,104]$ able to concentrate damaged DNA at the early stages of the DNA strand break response in order to undergo spatially controlled PAR-dependent phase separation $[101,104]$.

\subsection{DNA Damage Sensing by the Phase Separation of FUS?}

Even though the nucleus, unlike the cytoplasm, does not contain membrane-bound organelles, the nucleus is a highly organised structure with separate proteinaceous and nucleic-acid-rich subnuclear compartments that have special morphology and specific composition of protein-nucleic acid complexes and are functionally specialised [105]. It was recently proposed that many DNA- or RNA-containing structures in the nucleus are assembled through a physicochemical process called LLPS [30,105-107]. In fact, LLPS of protein or protein-nucleic acid mixtures is now regarded as the principal mechanism behind the formation of protein-rich membrane-less compartments in the cell [29,105-108]. In eukaryotes, an abundant group of RBPs-that are intrinsically disordered proteins (IDPs) with prion-like properties-represents key factors that contribute to the creation of these compartments in the cell through the phase separation mechanism [30,64,65,67]. Among these proteins is FUS, which is presently intensively studied due to its ability to undergo reversible phase separation in vitro and in vivo (thereby generating protein-rich droplets, hydrogels and amyloid aggregates) and due to its link with major neurodegenerative diseases such as ALS $[56,64,79,109,110]$. Moreover, other biomolecules, such as RNA and PAR, influence the phase behaviour of FUS and can drive phase separation $[17,56,101,111]$. For example, functional interactions between RNA and FUS are assumed to play a key role in the dynamics of compartments among which we can find mRNA-rich stress granules $[71,74,78,83,112]$. The similarity to its association with RNA and the evidence of FUS condensation at a damaged-DNA site mediated by its interaction with PAR both in vitro and in cell systems have been reported $[17,38,51,56,101]$. In vitro, FUS has been found to interact with purified PAR directly, and its binding to PAR promotes LLPS of FUS and possibly its aggregation $[16,17,38,56,101]$. In addition, the appearance of FUS-rich assemblies in nuclear damage regions observed in vivo depends on PAR synthesised at DNA damage sites $[17,56]$. Accordingly, the interaction of FUS with PAR and the ensuing phase separation may be an important process underlying the formation of DNA repair compartments $[17,56,101]$. Nevertheless, the exact molecular mechanism(s) responsible for the creation of these compartments and their possible functions are difficult to address in a cellular context. At least three mechanisms have been considered to explain the formation of protein-rich DNA compartments in the nucleus, namely, (i) a cooperative binding of proteins to specific sites along DNA without phase separation, (ii) polymer-polymer phase separation in which proteins form molecular 'bridges' between different binding sites and (iii) LLPS of IDPs and nucleic acids $[106,113]$. So far, it is not clear what types of mechanisms take place in the context of a compartment generated to orchestrate DNA repair 
after FUS is directed to DNA damage sites upon PARP1 activation. Single-molecule experiments have partly shed light on this important issue. The atomic force microscopy single-molecule technique has been used to analyse the assemblies orchestrated by FUS at DNA damage sites after PARP1 activation in a reconstituted molecular system that includes mRNA to mimic mRNA targets of FUS in the nucleus, damaged DNA, PARP1 to recognise damage sites in DNA, NAD ${ }^{+}$to trigger the synthesis of PAR by PARP1 and PARG to hydrolyse PAR [101]. Indeed, in the presence of free PAR, FUS can assemble into large PAR-containing aggregates (Figure 6a). Of note, when auto-PARylated PARP1 is still complexed with a DNA damage site, the FUS interaction with PAR gives rise to large aggregates in which DNA damage sites are condensed (Figure 6b).

(a)
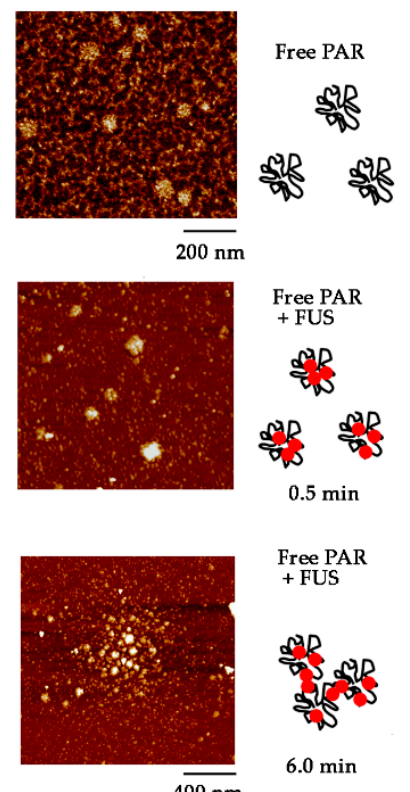

$400 \mathrm{~nm}$

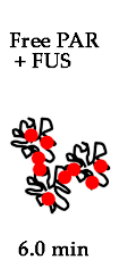

(b)
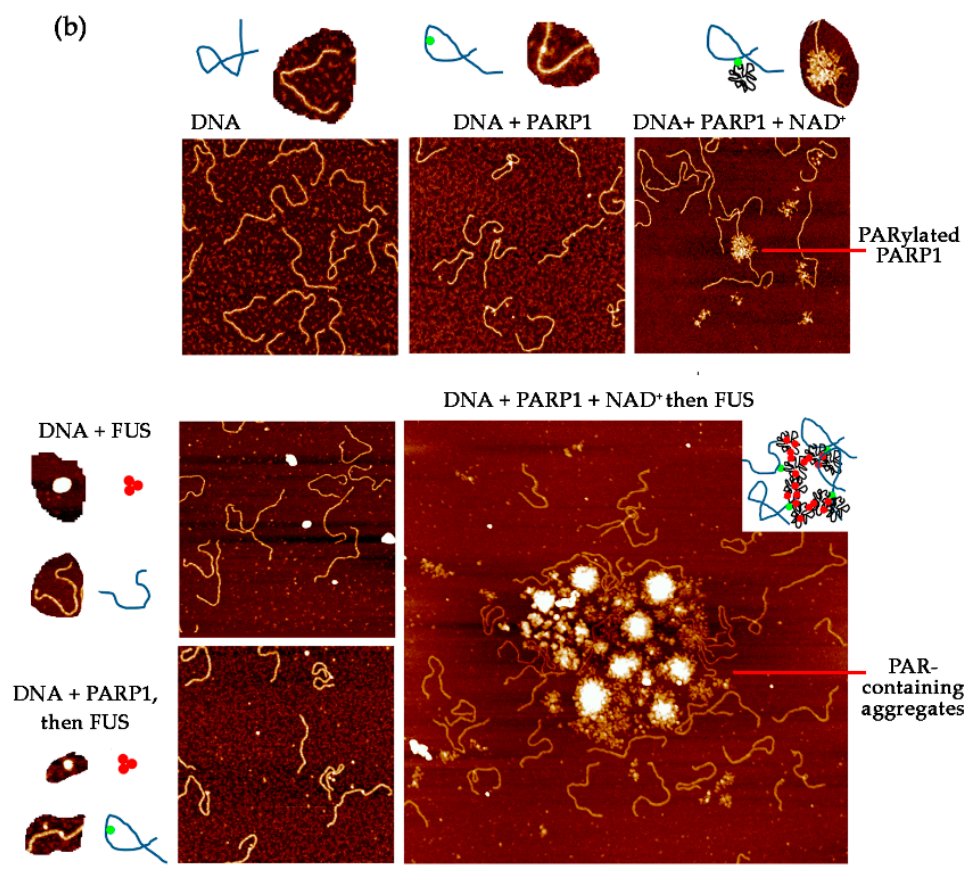

$\overline{200 \mathrm{~nm}}$

Figure 6. The formation of large DNA-rich assemblies in the presence of FUS after PAR synthesis by PARP1 [101]. (a) Representative AFM images of PAR:FUS complexes at different incubation times. PAR: $1 \mu \mathrm{M}$; FUS: $40 \mathrm{nM}$. (b) Representative AFM images of 1200-bp nicked DNA (1.25 nM) after incubation with PARP1 $(3 \mathrm{nM})$ for $5 \mathrm{~min}$ in the presence or absence of $\mathrm{NAD}^{+}(0.3 \mathrm{mM})$ followed by the addition of FUS (40 $\mathrm{nM})$ and incubation for $1 \mathrm{~min}$.

Thus, damaged DNA is rapidly confined to multi-protein complexes assembled after the FUS interaction with PARylated PARP1, thereby initiating the spatial segregation of damaged DNA (from intact DNA) into dynamical compartments [101]. The following sequence of events may then take place: (i) the site-specific interaction of PARP1 with damaged DNA triggers PAR synthesis to direct FUS to DNA damage sites, (ii) FUS induces the compartmentalisation of damaged DNA if PARylated PARP1 still bound to damaged DNA $[101,114]$. In agreement with the latter point, FUS fails to support the assembly of the DNA-rich compartments in mixtures of damaged DNA and free PAR [101]. Moreover, PAR hydrolysis by PARG induces the disassembly of DNA-rich compartments and a release of FUS. Due to the PARG/ARH3 activities, the formation of damaged-DNA-rich compartments by FUS is dynamic and reversible, which is important for the turnover of DNA repair. Taken together, these observations suggest that FUS-mediated DNA repair compartments form not only through the LLPS capacity of FUS but may also be due to mechanisms underlying the binding of PARP1 to damaged DNA and then bridging by FUS after PAR synthesis (Figure 7). Thus, PARP1 binding to damaged DNA proceeds without phase separation, then the interaction of FUS with PARylated PARPs bridges damage sites in close spatial proximity to each other. 


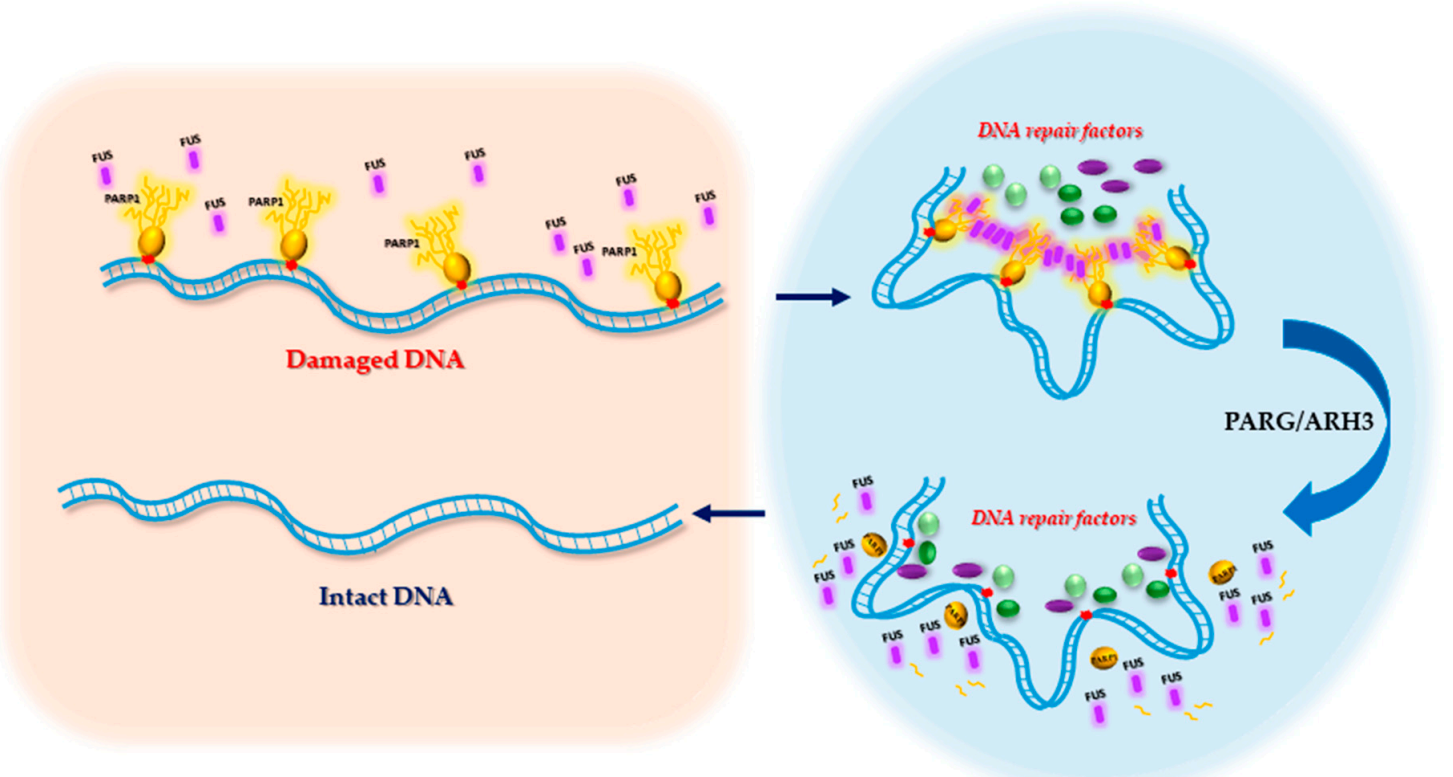

Figure 7. Creation of a repair compartment driven by the interaction of FUS with PAR. The compartment is a cluster of PARylated PARP1 bound by FUS that is concentrated to create a genomic region that is active in terms of DNA repair and may concentrate damaged DNA with subsequent recruitment of DNA repair proteins. PARG dissociates damaged DNA compartments by hydrolyzing PAR.

Because some of the DNA repair factors interact with PAR [25,99,115-117], they can be in turn directed to the damaged-DNA-rich FUS/PAR compartments. Such a function in the organisation of DNA damage repair has previously been attributed to PAR itself $[116,118]$, but the presence of an IDP like FUS may be necessary to increase the capacity of PAR to recruit DNA repair factors and/or to concentrate the DNA damage sites within the compartment. Consequently, the FUS interaction with PAR not only results in the emergence of damaged-DNA-rich compartments but also can stimulate the assembly of the relevant DNA machineries. Altogether, these findings provide new insights into DNA repair regulation at least for SSB repair and BER, because these processes are highly dependent on PARP1 activation [102,103]. The interaction of key proteins of BER/SSB repair pathway (Figure 4) such as AP endonuclease1, XRCC1 and DNA polymerase $\beta$ with PAR was recently demonstrated [117]. FUS directly affects the efficiency of a repair process, for example, nick sealing by DNA ligase III at the last step of the repair pathways [40]. The spatiotemporal control of FUS/PAR-rich damaged-DNA compartments is most likely complicated and highly regulated, with a probable critical role of additional protein factors and phosphatases and/or kinases that remain to be identified. The hydrolysis of these compartments by PARG causes their dissociation and ensures reversibility of the whole repair process.

Thus, FUS may generate dynamic compartments in which damaged DNA accumulates, and this event should facilitate the recognition of DNA lesions by DNA repair proteins because of the relative increase in concentrations of damaged DNA and of repair factors within the compartments. The increase in the local concentration of DNA lesions and repair factors should accelerate DNA repair and its turnover in the cell.

\section{Conclusions}

Lately, a number of fundamental discoveries were made concerning the functions of RBPs in the DDR; they may profoundly change the concept of the regulation and organisation of DNA repair processes in the cell. Notably, the recent finding that RBPs with prion-like domains undergo phase separation points to the participation of RBPs in the formation of DNA damage-induced compartments $[17,19,56,101,104]$. In this regard, the interaction of RBPs with the PAR produced in 
response to DNA damage is currently receiving increasing attention because PAR not only contributes to the recruitment of RBPs to a DNA repair site but also promotes their LLPS.

Since the discovery of the PAR-dependent recruitment of FUS to DNA repair foci in 2013 [51], there has been a substantial increase in the number of research articles confirming the role of FUS in DNA repair, thereby nurturing special interest in the question which molecular mechanisms may enable FUS to play a part in the DDR $[33,34]$. FUS seems to be involved in the DDR through an interaction with DNA repair intermediates, DNA repair factors and DNA damage signalling molecules like PAR [33,34]. Furthermore, FUS, having a self-adhesive LCD, can undergo phase separation $[53,55,56,65,109,110]$. Therefore, FUS-PAR interactions during DNA repair are possibly directly related to the assembly of damaged DNA with repair proteins and of transient repairosome compartments, which may carry out specific functions and implement spatiotemporal control over the DNA repair process [101]. To date, it is still unknown how FUS modulates DNA repair through compartmentalisation. Understanding the biological role of FUS in the generation of the repairosome and in its molecular composition and functions is necessary to clarify diverse characteristics of DNA repair-regulatory processes.

Further research into FUS functions and into the other protein members of the FET family, EWSR1 and TAF15, may advance the present knowledge on the mechanisms of prion-like-RBP-dependent regulation of DNA repair processes through the formation of compartments in human cells. Future investigation of how these RBPs orchestrate DNA repair pathways will deepen our understanding of the response of the cancer cell to genotoxic stress and will elucidate the mutations in these proteins associated with neurological diseases as well as will lay the foundation for the development of relevant innovative preventive or therapeutic modalities. Notably, in neurodegenerative diseases, FUS forms cytoplasmic inclusions that can be toxic by themselves or may impair the DNA-related function of nuclear FUS in ALS or FTLD patients. Given that PARPs' or PARG activities have been demonstrated to interfere with nucleocytoplasmic shuttling of FUS in the cytoplasm upon genotoxic stress [101,119], these data may extend the range of applications of PARPs or PARG inhibitors from cancer to neurodegenerative diseases [120].

Author Contributions: Writing-original draft preparation: M.V.S., D.P., O.I.L.; Visualisation: A.S.S., M.V.S.; Conceptualisation and Supervision: M.V.S., O.I.L. All authors have read and agreed to the published version of the manuscript.

Funding: This research was funded by the Russian Science Foundation, grant number 20-14-00086 (to M.S.), and by a Russian-state-funded budget project, grant number AAAA-A17-117020210022-4.

Conflicts of Interest: The authors declare no conflict of interest.

\section{References}

1. Lindahl, T.; Barnes, D.E. Repair of endogenous DNA damage. Cold Spring Harb. Symp. Quant. Biol. 2000, 65, 127-133. [CrossRef]

2. Torgovnick, A.; Schumacher, B. DNA repair mechanisms in cancer development and therapy. Front. Genet. 2015, 6, 157. [CrossRef]

3. Dietlein, F.; Thelen, L.; Reinhardt, H.C. Cancer-specific defects in DNA repair pathways as targets for personalized therapeutic approaches. Trends Genet. 2014, 30, 326-339. [CrossRef]

4. Tubbs, A.; Nussenzweig, A. Endogenous DNA damage as a source of genomic instability in cancer. Cell 2017, 168, 644-656. [CrossRef]

5. Ciccia, A.; Elledge, S.J. The DNA damage response: Making it safe to play with knives. Mol. Cell 2010, 40, 179-204. [CrossRef]

6. Sirbu, B.M.; Cortez, D. DNA damage response: Three levels of DNA repair regulation. Cold Spring Harb. Perspect. Biol. 2013, 5, a012724. [CrossRef]

7. Matsuoka, S.; Ballif, B.A.; Smogorzewska, A.; McDonald, E.R.; Hurov, K.E.; Luo, J.; Bakalarski, C.E.; Zhao, Z.; Solimini, N.; Lerenthal, Y.; et al. ATM and ATR substrate analysis reveals extensive protein networks responsive to DNA damage. Science 2007, 316, 1160-1166. [CrossRef] 
8. Dutertre, M.; Sanchez, G.; Barbier, J.; Corcos, L.; Auboeuf, D. The emerging role of pre-messenger RNA splicing in stress responses: Sending alternative messages and silent messengers. RNA Biol. 2011, 8, 740-747. [CrossRef]

9. Dutertre, M.; Vagner, S. DNA-damage response RNA-binding proteins (DDRBPs): Perspectives from a new class of proteins and their RNA targets. J. Mol. Biol. 2017, 429, 3139-3145. [CrossRef]

10. Paulsen, R.D.; Soni, D.V.; Wollman, R.; Hahn, A.T.; Yee, M.C.; Guan, A.; Hesley, J.A.; Miller, S.C.; Cromwell, E.F.; Solow-Cordero, D.E.; et al. A genome-wide siRNA screen reveals diverse cellular processes and pathways that mediate genome stability. Mol. Cell 2009, 35, 228-239. [CrossRef]

11. Adamson, B.; Smogorzewska, A.; Sigoillot, F.D.; King, R.W.; Elledge, S.J. A genome-wide homologous recombination screen identifies the RNA-binding protein RBMX as a component of the DNA-damage response. Nat. Cell Biol. 2012, 14, 318-328. [CrossRef]

12. Dutertre, M.; Lambert, S.; Carreira, A.; Amor-Guéret, M.; Vagner, S. DNA damage: RNA-binding proteins protect from near and far. Trends Biochem. Sci. 2014, 39, 141-149. [CrossRef]

13. Kai, M. Roles of RNA-binding proteins in DNA damage response. Int. J. Mol. Sci. 2016, 17, 310. [CrossRef]

14. Leung, A.K. Poly (ADP-ribose): An organizer of cellular architecture. J. Cell Biol. 2014, 205, 613-619. [CrossRef]

15. Hong, Z.; Jiang, J.; Ma, J.; Dai, S.; Xu, T.; Li, H.; Yasui, A. The role of hnRPUL1 involved in DNA damage response is related to PARP1. PLoS ONE 2013, 8, e60208. [CrossRef]

16. Leung, A.K. Poly (ADP-ribose): A dynamic trigger for biomolecular condensate formation. Trends Cell Biol. 2020, 30, 370-383. [CrossRef]

17. Altmeyer, M.; Neelsen, K.J.; Teloni, F.; Pozdnyakova, I.; Pellegrino, S.; Grøfte, M.; Rask, M.-B.D.; Streicher, W.; Jungmichel, S.; Nielsen, M.L.; et al. Liquid demixing of intrinsically disordered proteins is seeded by poly (ADP-ribose). Nat. Commun. 2015, 6, 8088. [CrossRef]

18. Sun, X.; Fu, K.; Hodgson, A.; Wier, E.M.; Wen, M.G.; Kamenyeva, O.; Xia, X.; Koo, L.Y.; Wan, F. Sam68 is required for DNA damage responses via regulating poly(ADP-ribosyl)ation. PLoS Biol. 2016, 14, e1002543. [CrossRef]

19. Jang, Y.; Elsayed, Z.; Eki, R.; He, S.; Du, K.P.; Abbas, T.; Kai, M. Intrinsically disordered protein RBM14 plays a role in generation of RNA: DNA hybrids at double-strand break sites. Proc. Natl. Acad. Sci. USA 2020, 117, 5329-5338. [CrossRef]

20. Althaus, F.R.; Kleczowska, H.E.; Malanga, M.; Muntener, C.R.; Pleschke, J.M.; Ebner, M.; Auer, B. Poly ADP-ribosylation: A DNA break signal mechanism. Mol. Cell Biochem. 1999, 193, 5-11. [CrossRef]

21. D'Amours, D.; Desnoyers, S.; D'Silva, I.; Poirier, G.G. Poly(ADP-ribosyl)ation reactions in the regulation of nuclear functions. Biochem. J. 1999, 342, 249-268. [CrossRef] [PubMed]

22. Caldecott, K.W. Protein ADP-ribosylation and the cellular response to DNA strand breaks. DNA Repair 2014, 19, 108-113. [CrossRef]

23. Kiehlbauch, C.C.; Aboul-Ela, N.; Jacobson, E.L.; Ringer, D.P.; Jacobson, M.K. High resolution fractionation and characterization of ADP-ribose polymers. Anal. Biochem. 1993, 208, 26-34. [CrossRef] [PubMed]

24. Alvarez-Gonzalez, R.; Jacobson, M.K. Characterization of polymers of adenosine diphosphate ribose generated in vitro and in vivo. Biochemistry 1987, 26, 3218-3224. [CrossRef]

25. Teloni, F.; Altmeyer, M. Readers of poly (ADP-ribose): Designed to be fit for purpose. Nucleic Acids Res. 2015, 44, 993-1006. [CrossRef]

26. Gagne, J.P.; Isabelle, M.; Lo, K.S.; Bourassa, S.; Hendzel, M.J.; Dawson, V.L.; Dawson, T.M.; Poirier, G.G. Proteome-wide identification of poly (ADP-ribose) binding proteins and poly (ADP-ribose)-associated protein complexes. Nucleic Acids Res. 2008, 36, 6959-6976. [CrossRef]

27. Jungmichel, S.; Rosenthal, F.; Altmeyer, M.; Lukas, J.; Hottiger, M.O.; Nielsen, M.L. Proteome-wide identification of poly(ADP-Ribosyl) ation targets in different genotoxic stress responses. Mol. Cell 2013, 52, 272-285. [CrossRef]

28. Babu, M.M. The contribution of intrinsically disordered regions to protein function, cellular complexity, and human disease. Biochem. Soc. Trans. 2016, 44, 1185-1200. [CrossRef]

29. Boeynaems, S.; Alberti, S.; Fawzi, N.L.; Mittag, T.; Polymenidou, M.; Rousseau, F.; Schymkowitz, J.; Shorter, J.; Wolozin, B.; Van Den Bosch, L.; et al. Protein phase separation: A new phase in cell biology. Trends Cell Biol. 2018, 28, 420-435. [CrossRef]

30. Darling, A.L.; Liu, Y.; Oldfield, C.J.; Uversky, V.N. Intrinsically Disordered Proteome of Human Membrane-Less Organelles. Proteomics 2018, 18, 1700193. [CrossRef] 
31. Jaunmuktane, Z.; Brandner, S. Invited Review: The role of prion-like mechanisms in neurodegenerative diseases. Neuropath. Appl. Neuro. 2019. [CrossRef]

32. Yang, S.; Warraich, S.T.; Nicholson, G.A.; Blair, I.P. Fused in sarcoma/translocated in liposarcoma: A multifunctional DNA/RNA binding protein. Int. J. Biochem. Cell Biol. 2010, 42, 1408-1411. [CrossRef]

33. Sama, R.R.K.; Ward, C.L.; Bosco, D.A. Functions of FUS/TLS from DNA repair to stress response: Implications for ALS. ASN Neuro 2014, 6, 1759091414544472. [CrossRef]

34. Wang, H.; Hegde, M.L. New mechanisms of DNA repair defects in fused in sarcoma-associated neurodegeneration: Stage set for DNA repair-based therapeutics? J. Exp. Neurosci. 2019, 13, 1179069519856358. [CrossRef]

35. Aman, P.; Panagopoulos, I.; Lassen, C.; Fioretos, T.; Mencinger, M.; Toresson, H.; Höglund, M.; Forster, A.; Rabbitts, T.H.; Ron, D.; et al. Expression Patterns of the human sarcoma-associated genes FUS and EWS and the genomic structure of FUS. Genomics 1996, 37, 1-8. [CrossRef]

36. Gardiner, M.; Toth, R.; Vandermoere, F.; Morrice, N.A.; Rouse, J. Identification and characterization of FUS/TLS as a new target of ATM. Biochem. J. 2008, 415, 297-307. [CrossRef]

37. Wang, W.Y.; Pan, L.; Su, S.C.; Quinn, E.J.; Sasaki, M.; Jimenez, J.C.; Mackenzie, I.R.; Huang, E.J.; Tsai, L.H. Interaction of FUS and HDAC1 regulates DNA damage response and repair in neurons. Nat. Neurosci. 2013, 16, 1383. [CrossRef]

38. Rulten, S.L.; Rotheray, A.; Green, R.L.; Grundy, G.J.; Moore, D.A.; Gomez-Herreros, F.; Hafezparast, M.; Caldecott, K.W. PARP-1 dependent recruitment of the amyotrophic lateral sclerosis-associated protein FUS/TLS to sites of oxidative DNA damage. Nucleic Acids Res. 2014, 42, 307-314. [CrossRef]

39. Deng, Q.; Holler, C.J.; Taylor, G.; Hudson, K.F.; Watkins, W.; Gearing, M.; Ito, D.; Murray, M.E.; Dickson, D.W.; Seyfried, N.T.; et al. FUS is phosphorylated by DNA-PK and accumulates in the cytoplasm after DNA damage. J. Neurosci. 2014, 34, 7802-7813. [CrossRef] [PubMed]

40. Wang, H.; Guo, W.; Mitra, J.; Hegde, P.M.; Vandoorne, T.; Eckelmann, B.J.; Mitra, S.; Tomkinson, A.E.; Van Den Bosch, L.; Hegde, M.L. Mutant FUS causes DNA ligation defects to inhibit oxidative damage repair in Amyotrophic Lateral Sclerosis. Nat. Commun. 2018, 9, 3683. [CrossRef]

41. Crozat, A.; Åman, P.; Mandahl, N.; Ron, D. Fusion of CHOP to a novel RNA-binding protein in human myxoid liposarcoma. Nature 1993, 363, 640. [CrossRef] [PubMed]

42. Rabbitts, T.H.; Forster, A.; Larson, R.; Nathan, P. Fusion of the dominant negative transcription regulator $\mathrm{CHOP}$ with a novel gene FUS by translocation $\mathrm{t}(12 ; 16)$ in malignant liposarcoma. Nat. Genet. 1993, 4 , 175-180. [CrossRef] [PubMed]

43. Law, W.J.; Cann, K.L.; Hicks, G.G. TLS, EWS and TAF15: A model for transcriptional integration of gene expression. Brief. Funct. Genomics 2006, 5, 8-14. [CrossRef]

44. Kovar, H. Dr. Jekyll and Mr. Hyde: The two faces of the FUS/EWS/TAF15 protein family. Sarcoma 2011, 2011, 837474. [CrossRef]

45. Iko, Y.; Kodama, T.S.; Kasai, N.; Oyama, T.; Morita, E.H.; Muto, T.; Okumura, M.; Fujii, R.; Takumi, T.; Tate, S.-I.; et al. Domain architectures and characterization of an RNA-binding protein, TLS. J. Biol. Chem. 2004, 279, 44834-44840. [CrossRef]

46. Lee, B.J.; Cansizoglu, A.E.; Süel, K.E.; Louis, T.H.; Zhang, Z.; Chook, Y.M. Rules for nuclear localization sequence recognition by karyopherin $\beta 2$. Cell 2006, 126, 543-558. [CrossRef] [PubMed]

47. Prasad, D.D.; Ouchida, M.; Lee, L.; Rao, V.N.; Reddy, E.S. TLS/FUS fusion domain of TLS/FUS-erg chimeric protein resulting from the $\mathrm{t}(16 ; 21)$ chromosomal translocation in human myeloid leukemia functions as a transcriptional activation domain. Oncogene 1994, 9, 3717-3729. [PubMed]

48. Zinszner, H.; Sok, J.; Immanuel, D.; Yin, Y.; Ron, D. TLS (FUS) binds RNA in vivo and engages in nucleo-cytoplasmic shuttling. J. Cell Sci. 1997, 110, 1741-1750.

49. Baechtold, H.; Kuroda, M.; Sok, J.; Ron, D.; Lopez, B.S.; Akhmedov, A.T. Human 75-kDa DNA-pairing protein is identical to the pro-oncoprotein TLS/FUS and is able to promote D-loop formation. J. Biol. Chem. 1999, 274, 34337-34342. [CrossRef]

50. Perrotti, D.; Bonatti, S.; Trotta, R.; Martinez, R.; Skorski, T.; Salomoni, P.; Grassilli, E.; Lozzo, R.V.; Cooper, D.R.; Calabretta, B. TLS/FUS, a pro-oncogene involved in multiple chromosomal translocations, is a novel regulator of BCR/ABL-mediated leukemogenesis. EMBO J. 1998, 17, 4442-4455. [CrossRef] 
51. Mastrocola, A.S.; Kim, S.H.; Trinh, A.T.; Rodenkirch, L.A.; Tibbetts, R.S. The RNA binding protein fused in sarcoma (FUS) functions downstream of PARP in response to DNA damage. J. Biol. Chem. 2013, 288, 24731-24741. [CrossRef] [PubMed]

52. Kwon, I.; Kato, M.; Xiang, S.; Wu, L.; Theodoropoulos, P.; Mirzaei, H.; Han, T.; Xie, S.; Corden, J.L.; McKnight, S.L. Phosphorylation-regulated binding of RNA polymerase II to fibrous polymers of low-complexity domains. Cell 2013, 155, 1049-1060. [CrossRef] [PubMed]

53. Kato, M.; Han, T.W.; Xie, S.; Shi, K.; Du, X.; Wu, L.C.; Mirzaei, H.; Goldsmith, E.J.; Longgood, J.; Pei, J.; et al. Cell-free formation of RNA granules: Low complexity sequence domains form dynamic fibers within hydrogels. Cell 2012, 149, 753-767. [CrossRef] [PubMed]

54. Shang, Y.; Huang, E.J. Mechanisms of FUS mutations in familial amyotrophic lateral sclerosis. Brain Res. 2016, 1647, 65-78. [CrossRef] [PubMed]

55. Han, T.W.; Kato, M.; Xie, S.; Wu, L.C.; Mirzaei, H.; Pei, J.; Chen, M.; Xie, Y.; Allen, J.; Xiao, G.; et al. Cell-free formation of RNA granules: Bound RNAs identify features and components of cellular assemblies. Cell 2012, 149, 768-779. [CrossRef] [PubMed]

56. Patel, A.; Lee, H.O.; Jawerth, L.; Maharana, S.; Jahnel, M.; Hein, M.Y.; Stoynov, S.; Mahamid, J.; Saha, S.; Franzmann, T.M.; et al. A liquid-to-solid phase transition of the ALS protein FUS accelerated by disease mutation. Cell 2015, 162, 1066-1077. [CrossRef]

57. Webber, C.J.; Lei, S.E.; Wolozin, B. The pathophysiology of neurodegenerative disease: Disturbing the balance between phase separation and irreversible aggregation. Dancing Protein Clouds: Intrinsically Disordered Proteins in Health and Disease. Prog. Mol. Biol. Transl. Sci. 2020, 174, 187-223.

58. Franzmann, T.M.; Alberti, S. Prion-like low-complexity sequences: Key regulators of protein solubility and phase behavior. J. Biol. Chem. 2019, 294, 7128-7136. [CrossRef]

59. King, O.D.; Gitler, A.D.; Shorter, J. The tip of the iceberg: RNA-binding proteins with prion-like domains in neurodegenerative disease. Brain Res. 2012, 1462, 61-80. [CrossRef]

60. Sun, Z.; Diaz, Z.; Fang, X.; Hart, M.P.; Chesi, A.; Shorter, J.; Gitler, A.D. Molecular determinants and genetic modifiers of aggregation and toxicity for the ALS disease protein FUS/TLS. PLoS Biol. 2011, 9, e1000614. [CrossRef]

61. Li, P.; Banjade, S.; Cheng, H.C.; Kim, S.; Chen, B.; Guo, L.; Llaguno, M.; Hollingsworth, J.V.; King, D.S.; Banani, S.F.; et al. Phase transitions in the assembly of multivalent signalling proteins. Nature 2012, 483, 336. [CrossRef]

62. Burke, K.A.; Janke, A.M.; Rhine, C.L.; Fawzi, N.L. Residue-by-residue view of in vitro FUS granules that bind the C-terminal domain of RNA polymerase II. Mol. Cell 2015, 60, 231-241. [CrossRef] [PubMed]

63. Lin, Y.; Protter, D.S.; Rosen, M.K.; Parker, R. Formation and maturation of phase-separated liquid droplets by RNA-binding proteins. Mol. Cell 2015, 60, 208-219. [CrossRef]

64. Murthy, A.C.; Dignon, G.L.; Kan, Y.; Zerze, G.H.; Parekh, S.H.; Mittal, J.; Fawzi, N.L. Molecular interactions underlying liquid- liquid phase separation of the FUS low-complexity domain. Nat. Struct. Mol. Biol. 2019, 26, 637-648. [CrossRef]

65. Wang, J.; Choi, J.M.; Holehouse, A.S.; Lee, H.O.; Zhang, X.; Jahnel, M.; Maharana, S.; Lemaitre, R.; Pozniakovsky, A.; Drechsel, D.; et al. A molecular grammar governing the driving forces for phase separation of prion-like RNA binding proteins. Cell 2018, 174, 688-699. [CrossRef] [PubMed]

66. Dormann, D.; Haass, C. Fused in sarcoma (FUS): An oncogene goes awry in neurodegeneration. Mol. Cell Neurosci. 2013, 56, 475-486. [CrossRef] [PubMed]

67. Gomes, E.; Shorter, J. The molecular language of membraneless organelles. J. Biol. Chem. 2019, $294,7115-7127$. [CrossRef] [PubMed]

68. Lin, Y.; Currie, S.L.; Rosen, M.K. Intrinsically disordered sequences enable modulation of protein phase separation through distributed tyrosine motifs. J. Biol. Chem. 2017, 292, 19110-19120. [CrossRef]

69. Nishimoto, Y.; Nakagawa, S.; Hirose, T.; Okano, H.J.; Takao, M.; Shibata, S.; Suyama, S.; Kuwako, K.-I.; Imai, T.; Murayama, S.; et al. The long non-coding RNA nuclear-enriched abundant transcript 1-2 induces paraspeckle formation in the motor neuron during the early phase of amyotrophic lateral sclerosis. Mol. Brain 2013, 6, 31. [CrossRef]

70. Yamazaki, T.; Chen, S.; Yu, Y.; Yan, B.; Haertlein, T.C.; Carrasco, M.A.; Tapia, J.C.; Zhai, B.; Das, R.; Lalancette-Hebert, M.; et al. FUS-SMN protein interactions link the motor neuron diseases ALS and SMA. Cell Rep. 2012, 2, 799-806. [CrossRef] 
71. Sama, R.R.K.; Ward, C.L.; Kaushansky, L.J.; Lemay, N.; Ishigaki, S.; Urano, F.; Bosco, D.A. FUS/TLS assembles into stress granules and is a prosurvival factor during hyperosmolar stress. J. Cell. Physiol. 2013, 228, 2222-2231. [CrossRef] [PubMed]

72. Gal, J.; Zhang, J.; Kwinter, D.M.; Zhai, J.; Jia, H.; Jia, J.; Zhu, H. Nuclear localization sequence of FUS and induction of stress granules by ALS mutants. Neurobiol. Aging 2011, 32, 2323.e27-2323.e40. [CrossRef] [PubMed]

73. Dormann, D.; Rodde, R.; Edbauer, D.; Bentmann, E.; Fischer, I.; Hruscha, A.; Than, M.E.; Mackenzie, I.R.A.; Capell, A.; Schmid, B.; et al. ALS-associated fused in sarcoma (FUS) mutations disrupt Transportin-mediated nuclear import. EMBO J. 2010, 29, 2841-2857. [CrossRef] [PubMed]

74. Bosco, D.A.; Lemay, N.; Ko, H.K.; Zhou, H.; Burke, C.; Kwiatkowski, T.J.; Sapp, P.; McKenna-Yasek, D.; Brown, R.H.; Hayward, L.J. Mutant FUS proteins that cause amyotrophic lateral sclerosis incorporate into stress granules. Hum. Mol. Genet. 2010, 19, 4160-4175. [CrossRef]

75. Ito, D.; Seki, M.; Tsunoda, Y.; Uchiyama, H.; Suzuki, N. Nuclear transport impairment of amyotrophic lateral sclerosis-linked mutations in FUS/TLS. Ann. Neurol. 2010, 69, 152-162. [CrossRef]

76. Vance, C.; Scotter, E.L.; Nishimura, A.L.; Troakes, C.; Mitchell, J.C.; Kathe, C.; Urwin, H.; Manser, C.; Miller, C.C.; Hortobágyi, T.; et al. ALS mutant FUS disrupts nuclear localization and sequesters wild-type FUS within cytoplasmic stress granules. Hum. Mol. Genet. 2013, 22, 2676-2688. [CrossRef]

77. Baron, D.M.; Kaushansky, L.J.; Ward, C.L.; Sama, R.R.K.; Chian, R.-J.; Boggio, K.J.; Quaresma, A.J.C.; Nickerson, J.A.; Bosco, D.A. Amyotrophic lateral sclerosis-linked FUS/TLS alters stress granule assembly and dynamics. Mol. Neurodegener. 2013, 8, 30. [CrossRef]

78. Shelkovnikova, T.A.; Robinson, H.K.; Connor-Robson, N.; Buchman, V.L. Recruitment into stress granules prevents irreversible aggregation of FUS protein mislocalized to the cytoplasm. Cell Cycle 2013, 12, 3383-3391. [CrossRef]

79. Shelkovnikova, T.A.; Robinson, H.K.; Southcombe, J.A.; Ninkina, N.; Buchman, V.L. Multistep process of FUS aggregation in the cell cytoplasm involves RNA-dependent and RNA-independent mechanisms. Hum. Mol. Genet. 2014, 23, 5211-5226. [CrossRef]

80. Sun, S.; Ling, S.C.; Qiu, J.; Albuquerque, C.P.; Zhou, Y.; Tokunaga, S.; Li, H.; Qiu, H.; Bui, A.; Yeo, G.W.; et al. ALS-causative mutations in FUS/TLS confer gain and loss of function by altered association with SMN and U1-snRNP. Nat. Commun. 2015, 6, 6171. [CrossRef]

81. Yoshimura, A.; Fujii, R.; Watanabe, Y.; Okabe, S.; Fukui, K.; Takumi, T. Myosin-Va facilitates the accumulation of mRNA/protein complex in dendritic spines. Curr. Biol. 2006, 16, 2345-2351. [CrossRef] [PubMed]

82. Fujii, R.; Takumi, T. TLS facilitates transport of mRNA encoding an actin-stabilizing protein to dendritic spines. J. Cell Sci. 2005, 118, 5755-5765. [CrossRef] [PubMed]

83. Andersson, M.K.; Ståhlberg, A.; Arvidsson, Y.; Olofsson, A.; Semb, H.; Stenman, G.; Nilsson, O.; Åman, P. The multifunctional FUS, EWS and TAF15 proto-oncoproteins show cell type-specific expression patterns and involvement in cell spreading and stress response. BMC Cell Biol. 2008, 9, 37. [CrossRef] [PubMed]

84. Zhou, Y.; Liu, S.; Öztürk, A.; Hicks, G.G. FUS-regulated RNA metabolism and DNA damage repair: Implications for amyotrophic lateral sclerosis and frontotemporal dementia pathogenesis. Rare Dis. 2014, 2, e1003895. [CrossRef]

85. Schärer, O.D. Chemistry and biology of DNA repair. Angew. Chem. Int. Ed. 2003, 42, 2946-2974. [CrossRef]

86. Ceccaldi, R.; Rondinelli, B.; D'Andrea, A.D. Repair pathway choices and consequences at the double-strand break. Trends Cell Biol. 2016, 26, 52-64. [CrossRef]

87. Beard, W.A.; Horton, J.K.; Prasad, R.; Wilson, S.H. Eukaryotic base excision repair: New approaches shine light on mechanism. Annu. Rev. Biochem. 2019, 88, 137-162. [CrossRef]

88. Hicks, G.G.; Singh, N.; Nashabi, A.; Mai, S.; Bozek, G.; Klewes, L.; Arapovic, D.; White, E.K.; Koury, M.J.; Oltz, E.M.; et al. Fus deficiency in mice results in defective B-lymphocyte development and activation, high levels of chromosomal instability and perinatal death. Nat. Genet. 2000, 24, 175. [CrossRef]

89. Kuroda, M.; Sok, J.; Webb, L.; Baechtold, H.; Urano, F.; Yin, Y.; Chung, P.; de Rooij, D.G.; Akhmedov, A.; Ashley, T.; et al. Male sterility and enhanced radiation sensitivity in TLS-/-mice. EMBO J. 2000, 19, 453-462. [CrossRef]

90. Guirouilh-Barbat, J.; Lambert, S.; Bertrand, P.; Lopez, B.S. Is homologous recombination really an error-free process? Front. Genet. 2014, 5, 175. [CrossRef] 
91. Yang, L.; Gal, J.; Chen, J.; Zhu, H. Self-assembled FUS binds active chromatin and regulates gene transcription. Proc. Natl. Acad. Sci. USA 2014, 111, 17809-17814. [CrossRef]

92. Dobbin, M.M.; Madabhushi, R.; Pan, L.; Chen, Y.; Kim, D.; Gao, J.; Ahanonu, B.; Pao, P.-C.; Qiu, Y.; Zhao, Y.; et al. SIRT1 collaborates with ATM and HDAC1 to maintain genomic stability in neurons. Nat. Neurosci. 2013, 16, 1008. [CrossRef]

93. Guerrero, E.N.; Wang, H.; Mitra, J.; Hegde, P.M.; Stowell, S.E.; Liachko, N.F.; Kraemer, B.C.; Garruto, R.M.; Rao, K.S.; Hegde, M.L. TDP-43/FUS in motor neuron disease: Complexity and challenges. Prog. Neurobiol. 2016, 145-146, 78-97. [CrossRef]

94. Takahama, K.; Takada, A.; Tada, S.; Shimizu, M.; Sayama, K.; Kurokawa, R.; Oyoshi, T. Regulation of telomere length by G-quadruplex telomere DNA-and TERRA-binding protein TLS/FUS. Chem. Biol. 2013, 20, 341-350. [CrossRef]

95. Alemasova, E.E.; Lavrik, O.I. Poly(ADP-ribosyl)ation by PARP1: Reaction mechanism and regulatory proteins. Nucleic Acids Res. 2019, 47, 3811-3827. [CrossRef]

96. Ali, S.O.; Khan, F.A.; Galindo-Campos, M.A.; Yélamos, J. Understanding specific functions of PARP-2: New lessons for cancer therapy. Am. J. Cancer Res. 2016, 6, 1842-1863.

97. Suskiewicz, M.J.; Palazzo, L.; Hughes, R.; Ahel, I. Progress and outlook in studying the substrate specificities of PARPs and related enzymes. FEBS J. 2020. [CrossRef]

98. Davidovic, L.; Vodenicharov, M.; Affar, E.B.; Poirier, G.G. Importance of poly(ADP-ribose) glycohydrolase in the control of poly(ADP-ribose) metabolism. Exp. Cell Res. 2001, 268, 7-13. [CrossRef]

99. Mashimo, M.; Moss, J. Functional role of ADP-ribosyl-acceptor hydrolase 3 in poly(ADP-ribose) polymerase-1 response to oxidative stress. Curr. Protein Pept. Sc. 2016, 17, 633-640. [CrossRef]

100. Kamaletdinova, T.; Fanaei-Kahrani, Z.; Wang, Z.Q. The Enigmatic Function of PARP1: From PARylation Activity to PAR Readers. Cells 2019, 8, 1625. [CrossRef]

101. Singatulina, A.S.; Hamon, L.; Sukhanova, M.V.; Desforges, B.; Joshi, V.; Bouhss, A.; Lavrik, O.I.; Pastré, D. PARP-1 activation directs FUS to DNA damage sites to form PARG-reversible compartments enriched in damaged DNA. Cell Rep. 2019, 27, 1809-1821. [CrossRef] [PubMed]

102. Martin-Hernandez, K.; Rodriguez-Vargas, J.M.; Schreiber, V.; Dantzer, F. Expanding functions of ADP-ribosylation in the maintenance of genome integrity. Semin. Cell Dev. Biol. 2017, 63, 92-101. [CrossRef]

103. Khodyreva, S.N.; Lavrik, O.I. Poly(ADP-Ribose) polymerase 1 as a key regulator of DNA repair. Mol. Biol. 2016, 50, 580-595. [CrossRef]

104. Lenzken, S.C.; Levone, B.R.; Filosa, G.; Antonaci, M.; Conte, F.; Kizilirmak, C.; Mühlemann, O. FUS-dependent phase separation initiates double-strand break repair. bioRxiv 2019, 798884. [CrossRef]

105. Sleeman, J.E.; Trinkle-Mulcahy, L. Nuclear bodies: New insights into assembly/dynamics and disease relevance. Curr. Opin. Cell Biol. 2014, 28, 76-83. [CrossRef]

106. Erdel, F.; Rippe, K. Formation of chromatin subcompartments by phase separation. Biophys. J. 2018, 114, 2262-2270. [CrossRef]

107. Yoshizawa, T.; Nozawa, R.S.; Jia, T.Z.; Saio, T.; Mori, E. Biological phase separation: Cell biology meets biophysics. Biophys. Rev. 2020, 12, 519-539. [CrossRef]

108. Yoo, H.; Triandafillou, C.; Drummond, D.A. Cellular sensing by phase separation: Using the process, not just the products. J. Boil. Chem. 2019, 294, 7151-7159. [CrossRef]

109. Murakami, T.; Qamar, S.; Lin, J.Q.; Schierle, G.S.; Rees, E.; Miyashita, A.; Costa, A.R.; Dodd, R.B.; Chan, F.T.; Michel, C.H.; et al. ALS/FTD Mutation-induced phase transition of FUS liquid droplets and reversible hydrogels into irreversible hydrogels impairs RNP granule function. Neuron 2015, 88, 678-690. [CrossRef]

110. Murray, D.T.; Kato, M.; Lin, Y.; Thurber, K.R.; Hung, I.; McKnight, S.L.; Tycko, R. Structure of FUS protein fibrils and its relevance to self-assembly and phase separation of low-complexity domains. Cell 2017, 171, 615-627. [CrossRef]

111. Niaki, A.G.; Sarkar, J.; Cai, X.; Rhine, K.; Vidaurre, V.; Guy, B.; Hurst, M.; Lee, J.C.; Koh, H.R.; Guo, L.; et al. Loss of dynamic RNA interaction and aberrant phase separation induced by two distinct types of ALS/FTD-Linked FUS mutations. Mol. Cell 2020, 77, 82-94. [CrossRef]

112. Bentmann, E.; Neumann, M.; Tahirovic, S.; Rodde, R.; Dormann, D.; Haass, C. Requirements for stress granule recruitment of fused in sarcoma (FUS) and TAR DNA-binding protein of $43 \mathrm{kDa}$ (TDP-43). J. Biol. Chem. 2012, 287, 23079-23094. [CrossRef] 
113. Weber, S.C. Evidence for and against liquid-liquid phase separation in the Nucleus. Non-Coding RNA 2019, 5,50 .

114. Sukhanova, M.V.; Abrakhi, S.; Joshi, V.; Pastre, D.; Kutuzov, M.M.; Anarbaev, R.O.; Pastre, D.; Lavrik, O.I. Single molecule detection of PARP1 and PARP2 interaction with DNA strand breaks and their poly (ADP-ribosyl) ation using high-resolution AFM imaging. Nucleic Acids Res. 2016, 44, e60. [CrossRef]

115. Pleschke, J.M.; Kleczkowska, H.E.; Strohm, M.; Althaus, F.R. Poly (ADP-ribose) binds to specific domains in DNA damage checkpoint proteins. J. Biol. Chem. 2000, 275, 40974-40980. [CrossRef]

116. Fisher, A.E.; Hochegger, H.; Takeda, S.; Caldecott, K.W. Poly (ADP-ribose) polymerase 1 accelerates single-strand break repair in concert with poly(ADP-ribose) glycohydrolase. Mol. Cell Biol. 2007, 27, 5597-5605. [CrossRef]

117. Moor, N.A.; Vasil'eva, I.A.; Kuznetsov, N.A.; Lavrik, O.I. Human apurinic/apyrimidinic endonuclease 1 is modified in vitro by poly (ADP-ribose) polymerase 1 under control of the structure of damaged DNA. Biochimie 2020, 168, 144-155. [CrossRef]

118. Liu, C.; Vyas, A.; Kassab, M.A.; Singh, A.K.; Yu, X. The role of poly ADP-ribosylation in the first wave of DNA damage response. Nucleic Acids Res. 2017, 45, 8129-8141. [CrossRef]

119. Naumann, M.; Pal, A.; Goswami, A.; Lojewski, X.; Japtok, J.; Vehlow, A.; Naujock, M.; Günther, R.; Jin, M.; Stanslowsky, N. Impaired DNA damage response signaling by FUS-NLS mutations leads to neurodegeneration and FUS aggregate formation. Nature Commun. 2018, 9, 335. [CrossRef]

120. McGurk, L.; Rifai, O.M.; Bonini, N.M. Poly(ADP-ribosylation) in age-related neurological disease. Trends Genet. 2019, 35, 601-613. [CrossRef]

(C) 2020 by the authors. Licensee MDPI, Basel, Switzerland. This article is an open access article distributed under the terms and conditions of the Creative Commons Attribution (CC BY) license (http://creativecommons.org/licenses/by/4.0/). 